Ingeniería

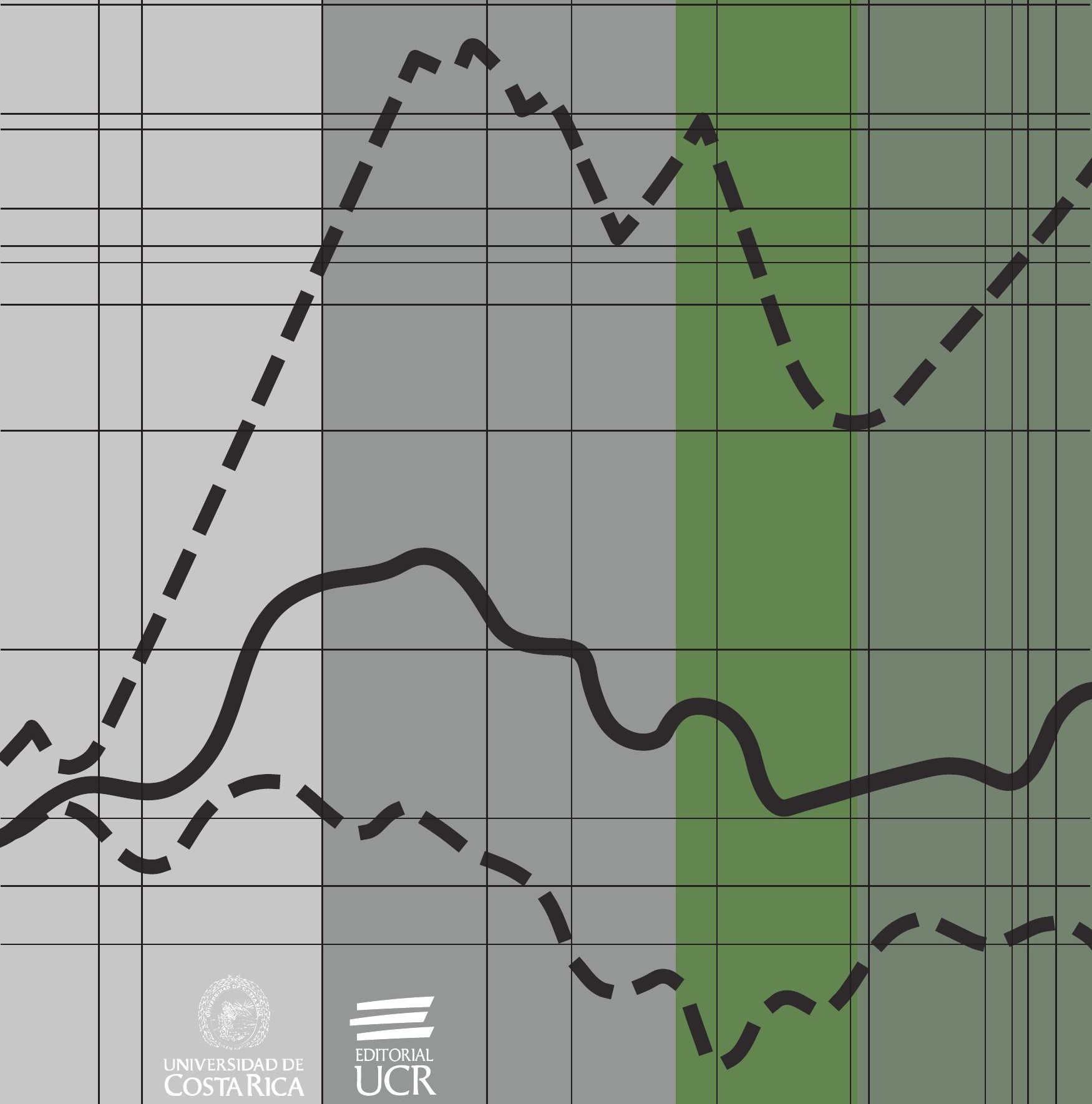




\title{
Effect of Temperature-Time on the Sterilization Process for a Jacketed Bioreactor System: Application of a Ratkowsky Nonlinear Model
}

\section{Efecto de la relación temperatura-tiempo en el proceso de esterilización para biorreactores enchaquetados: Aplicación de un modelo no lineal de Ratkowsky}

\author{
Jéssica Montero-Zamora \\ National Center for Advanced Technology, National Center of \\ Biotechnology Innovations, Bioprocess Unit, San José, Costa Rica. \\ Iray Mata Araya \\ National Center for Advanced Technology, National Center of \\ Biotechnology Innovations, Bioprocess Unit, San José, Costa Rica. \\ Manuel Molina Córdoba \\ University of Costa Rica, Faculty of Engineering, \\ Department of Chemical Engineering, San José, Costa Rica. \\ Francisco Aguilar Cascante \\ National Center for Advanced Technology, National Center of \\ Biotechnology Innovations, Bioprocess Unit, San José, Costa Rica.
}

\begin{abstract}
Steam sterilization is a technique widely implemented in different biotechnological processes -among them the growth of microorganisms in bioreactors-, which require initial aseptic conditions. In the present research, the relationship between lethality and death rate of Bacillus cereus grown in 7-liter stirred-tank jacketed bioreactors was investigated, with sugar cane molasses as a carbon source. The sterilization process was tested with an industrial autoclave within data loggers in bioreactors, which measure the temperature in the cold point to quantify the accumulated lethality. Through data analysis, a contour plot allows a graphical prediction of the microbiological sterilization results in terms of colony forming units (CFU).
\end{abstract}


The study shows that there is a range between 16 and 20 minutes, approaching $123{ }^{\circ} \mathrm{C}$, with a null presence of contaminant microorganisms. The surface chart demonstrates the existing non-linear relationship between the variables temperature and time involved. A positive correlation was observed using a Ratkowsky mathematical model with a 0,971 correlation coefficient and the estimated value of $\alpha=11,04$ and $\beta=-1,49$ for the non-linear model of parameterization. With these results, it is possible to predict the $\mathrm{CFU}$ based on $\mathrm{F}_{0}$ data. This could provide an interesting basis for future sterilization practices and a methodology as a starting point for sterilization trials in industry and save time and costs.

Keywords:

Bioengineering, fermentation, autoclaving, heat transfer, aseptic.

\section{Resumen}

La esterilización con vapor húmedo es una técnica ampliamente utilizada en diferentes procesos biotecnológicos, entre ellos, el crecimiento de microorganismos en biorreactor, proceso que requiere condiciones asépticas. En la presente investigación, se estudió la relación entre letalidad y tasa de muerte del Bacillus cereus en un biorreactor enchaquetado de 7 litros, utilizando melaza como fuente de carbono. El proceso de esterilización fue realizado en una autoclave industrial con registros de temperatura en tiempo real colocados dentro del punto frío del biorreactor con el fin de cuantificar la letalidad acumulada. El análisis de los datos experimentales dio como resultado un gráfico de contorno que permite predecir el resultado de la esterilización en términos de unidades formadoras de colonias (UFC). El caso en estudio muestra que existe un intervalo entre los 16 - 20 minutos a una temperatura cercana a los $123^{\circ} \mathrm{C}$ donde es posible eliminar en su totalidad el microorganismo contaminante. La superficie de respuesta demuestra que existe una relación no lineal entre las variables tiempo y temperatura, involucradas en el tratamiento térmico. Se observó una correlación positiva al utilizar el modelo matemático no lineal de Ratkowsky con un coeficiente de 0,971 y valores de $\alpha=11,04$ y $\beta=-1,49$ para la parametrización del modelo no lineal. Con los resultados obtenidos es posible predecir el valor de UFC presentes en el medio de cultivo para un valor determinado de $\mathrm{F}_{0}$, lo cual puede ser de amplio interés en procesos de esterilización industrial, con el fin de ahorrar tiempo y costos de operación.

\section{Palabras clave:}

Bioingeniería, fermentación, autoclavar, transferencia de calor, aséptico. 


\section{INTRODUCTION}

Before the bioreactor inoculation with the microorganism of interest, fermentation media is typically sterilized to remove microbial population (Armenante \& Leskowicz, 1990). The most commonly used sterilization method is moist heating with use of pressurized steam at $0,72 \mathrm{kPa}\left(15 \mathrm{lbs} \mathrm{in}^{-2}\right)$; if the air has been evacuated from the autoclave's chamber and the atmosphere is saturated with steam, the corresponding temperature is $121{ }^{\circ} \mathrm{C}$ (Boeck et al., 1988).

The main objective of autoclaving is to inactivate undesirable contaminating microorganisms. The alteration of media composition during sterilization can be a secondary and undesired effect through one or more mechanisms, for example: degradation, hydrolysis, conjugation and formation of insoluble compounds (Boeck, Alford, Pieper, \& Huber, 1989; Fernlund, Mobuchon, \& Zobeiry, 2018; Munarin, Bozzini, Visai, Tanzi, \& Petrini, 2013).

Sterilization is an operation that must be evaluated for every specific process (Schneider, 2014). Determining required conditions to achieve a sterile system has both practical and theoretical implications, for which it is important to design a procedure that will guarantee sterilization without unnecessary exposure to the destructive action of high temperatures, and at the same time to minimize energy consumption (Lau, Reizes, Timchenko, Kara, \& Kornfeld, 2015).

In order to calculate the death rate achieved during the sterilization process, it is necessary to study in advance the temperature-time profiles of both the culture medium inside the bioreactor, as well as the temperature in the autoclave chamber.

The ISO standard for moist heat sterilization of health care products dictates a number of acceptable time and temperature combinations recognized by some pharmacopoeias (Iso/Ts $17665-2: 2009,2009$ ). The combinations $121{ }^{\circ} \mathrm{C}-15 \mathrm{~min}, 126{ }^{\circ} \mathrm{C}-10 \mathrm{~min}, 134$ ${ }^{\circ} \mathrm{C}-3 \mathrm{~min}$ are the minimum temperature and time established for obtaining adequate levels of microbial lethality during the sterilization process. These parameters are built on the overkill concept where a safety factor has been developed for saturated steam or water in contact with the microorganisms present in the medium and the inside of the bioreactor (Iso/Ts 17665-2:2009, 2009).

Microbial inactivation capability of the heat sterilization process is a parameter that is expressed as an $F$ value $\left(F_{0}\right)$ (Boca, Pretorius, Gochin, Chapoullie, \& Apostolides, 2002). This parameter is a unit of lethality that is defined as the equivalent time at $121^{\circ} \mathrm{C}$ in order to destroy spores or vegetative cells of a particular organism (Choi, Cheigh, \& Chung, 2013). The total $F_{0}$ value of a process can be calculated by the integration of the lethal rates in regards of the time at different temperature intervals (Boca et al., 2002).

The decrease in the microbial population generally follows a first order kinetic model by equation (1), which follows the integration for a fixed value of $k_{d}$ (Huang, Hwang, \& Phillips, 2011).

$$
\frac{d N}{d t}=-k_{d} N
$$


If $k_{d}$ is a known value, this equation allows to calculate the number of viable microorganisms after a determined exposure time $(\mathrm{t})$. However, usually the initial population is unknown and most likely heterogeneous. For this reason, heat resistant strains of Bacillus stearothermophilus, with known spore concentrations have been used as biological indicators for steam sterilization in laboratory and industrial processes (Noble, 1992).

The thermal deactivation kinetics of $B$. stearothermophilus has been proven to follow the Arrhenius relationship with temperature (Singh, Hensler, \& Fuchs, 1989).

$$
\begin{aligned}
& \ln \left(\frac{N}{N_{0}}\right)=-k_{d} t \\
& \log N-\log N_{0}=-\frac{k_{d}}{2,303} t
\end{aligned}
$$

The previous expression is related to the definition of the D value in equation (4). This parameter is defined as the decimal reduction time; the time required to reduce a microbial population by a factor of 10 of its initial value at constant temperature (Wood, Lemieux, Betancourt, Kariher, \& Griffin, 2008).

$$
\log N_{0}-\log N=\frac{t}{D}
$$

When D value is given for two different temperatures, it is expressed as:

$$
\frac{D_{T_{1}}}{D_{T_{2}}}=10^{\frac{T_{2}-T_{1}}{Z}}
$$

By comparison, between equations (3) and (4)

$$
k_{d}=\frac{2,303}{D}
$$

The mathematical expression for lethality (see equation 8) is stated as the relationship among equations (4) and (5).

$$
\frac{d(\log N)}{d t}=\frac{-1}{D_{T_{2}} 10^{\frac{T_{2}-T_{1}}{Z}}}
$$




$$
F_{0}=D_{T_{2}}\left[\log \left(N_{0}\right)-\log (N)\right]=\int_{t_{0}}^{t_{n}} 10^{\left(\frac{T_{1}-T_{2}}{z}\right)} d t
$$

Equation (8) includes the $\mathrm{z}$ value known as the temperature sensitivity parameter, which represents a temperature range which results in a ten-fold change in $D$ values (Ates, Skipnes, Rode, \& Lekang, 2016).

Nonlinear regression models describe the relationship between a response and a predictor (Burghaus \& Dette, 2014). In microbiology studies, mathematical models are used to describe the behavior of microorganisms under different physical and chemical conditions (Zwietering, de Koos, Hasenack, de Witt, \& van't Riet, 1991). Several models have been suggested and tested for modeling the temperatures dependence of the bacterial behavior. In this paper, we use the parameterization consideration described by Ratkowsky (1993) in order to find the correlation between sterilization conditions and death rate.

The parameterization used is a nonlinear regression model, of two or more parameters, that is similar to linear in its original parameterization (Ratkowsky, 1993).

$$
y=\exp (a+b X)
$$

Thus, sterilization process in jacked stirred bioreactors is crucial and information is still scarce. The aim of the present work is to evaluate the relationship between lethality and death rate by the Ratkowsky model in order to predict reliable sterilization parameters.

\section{MATERIALS AND METHODS}

\section{Medium}

The carbon source used during the experimental trials was food grade molasses from sugar cane $(30 \mathrm{~g} / \mathrm{L})$ with buffered peptone water as a solvent (Oxoid Microbiology Products). The medium had a pH between 6,8 and 7,2 with a sucrose content of 13,4 $\mathrm{g} / \mathrm{L}$ and a glucose content of $1,56 \mathrm{~g} / \mathrm{L}$.

\section{Bacterial strain}

The bacterial strain used in this study was Bacillus cereus isolated from food grade molasses from sugar cane described above and identified by $16 \mathrm{~S}$ ribosomal RNA gene (rDNA) amplicon analysis. The results obtained after the Basic Local Alignment Search Tool (BLAST ${ }^{\circledR}$ ) analysis were compared using the GenBank database of the National Center for Biotechnology Information (NCBI). 


\section{Experimental trials}

7-liter stirred-tank bioreactors were used for sterilization (Applikon, Schiedam, Netherlands) (See figure 1). These bioreactors were jacketed glass vessels with multiport stainless head plates. The bioreactors were assembled with all customary accessories and had an operating volume of 4 liters. Vessels were equipped with a data logger (MadgeTech, New Hampshire, United States of America) to monitor the temperature in real time. Bioreactors were sterilized in an industrial autoclave (Tuttnauer, Breda, Netherlands) (Karayannakidis, Apostolidis, \& Lee, 2014).

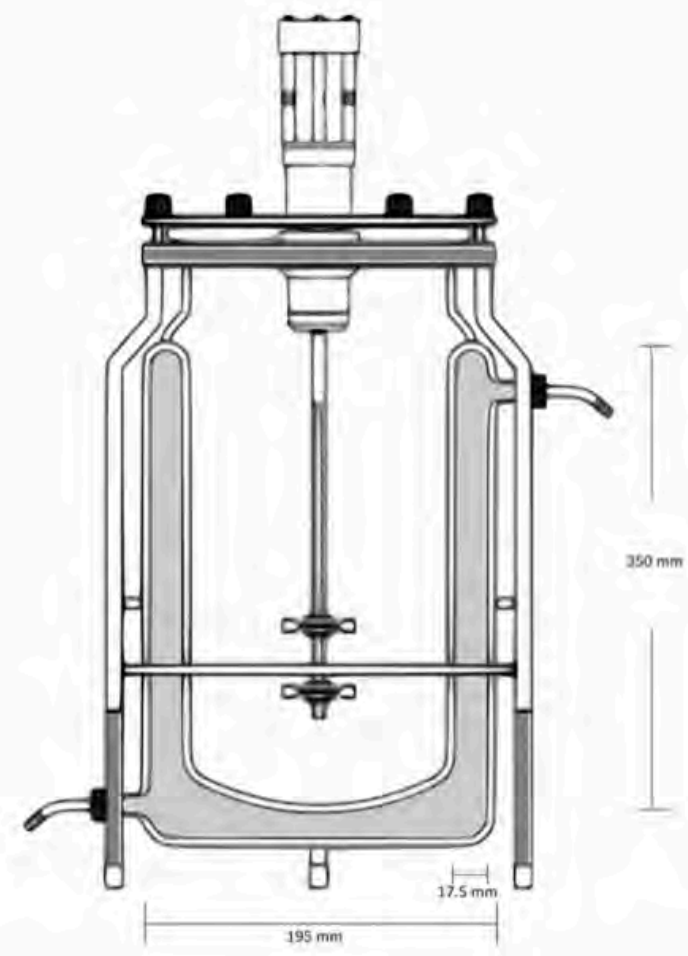

Figure 1. Schematic of a 7-liter stirred-tank jacketed bioreactor system with a jacket working volume of 1.2-liter

The bioreactors were placed in the middle of the autoclave chamber in an equidistant manner. The temperature probe from the autoclave chamber was positioned in the middle of both bioreactors. The temperature data loggers were placed inside the bioreactor, at one third of the total height from the base to the top. The experimental runs consisted of the following sterilization temperatures: $119^{\circ} \mathrm{C}, 121^{\circ} \mathrm{C}$ and $123^{\circ} \mathrm{C}$, and sterilization times: $10 \mathrm{~min}, 15 \mathrm{~min}, 20 \mathrm{~min}$, for a total of 9 experimental runs with duplicate bioreactors. The inoculum consisted of $1,40 \times 10^{9} \mathrm{CFU}$ (equivalent to 9,01 logarithmic scale) in every sterilization batch. 


\section{Microbial death rate}

After sterilization, three samples of $30 \mathrm{~mL}$ of the culture medium were taken for microbiological testing. Serial dilutions were spread over the surfaces of two 90 mm diameter sterile Petri dishes. Samples were plated on Tryptic Soy Agar (Oxoid Microbiology Products) and Potato Dextrose Agar (Oxoid Microbiology Products) in aerobic conditions. Plates were incubated at $35^{\circ} \mathrm{C}$ and $28{ }^{\circ} \mathrm{C}$, for 16 and 36 hours, respectively. Following incubation, $\mathrm{CFU}$ were counted. For all these tests, duplicates were assessed.

\section{Lethal rate calculations}

Experimental measurements from the data logger were downloaded to a computer using MadgeTech 2.5 software (MadgeTech, United States of America) in order to graph the temperature profile. Data was plotted using EXCEL ${ }^{\circledR}$ and the area under the plot was estimated utilizing Riemann sums to calculate the $F_{0}$ value (Padrón et al., 2001). The lethality obtained during cooling was not included in the $F_{0}$ calculation.

\section{Ratkowsky correlation}

The results of the UFC counts in function of the accumulated lethality of the experimental runs were analyzed with the software CurveExpert (Hyams Development, United States of America). Therefore, the non-linear model of Ratkowsky was chosen in the data analysis due to the fit between microbial growth and temperature (Ratkowsky, 1993).

\section{RESULTS AND DISCUSSION}

The ability of inactivating undesirable contaminating microorganisms and avoiding alteration of media composition during sterilization are keys issues in the development of effective sterilization processes. Due to this, there has been an increasing interest in understanding the relationship between lethality and heat processes on the bioreactor's sterilization. The purpose of this study was to investigate the relationship of sterilization parameters on lethality and death rate of Bacillus cereus by the Ratkowsky nonlinear model in order to predict sterilization efficacy.

The variables considered in the experimental procedures were death rate and viable microorganisms, in order to estimate the $F_{0}$ value in each experimental treatment and analyze the CFU results obtained under different sterilization conditions (Sherer, Hannemann, Rundell, \& Ramkrishna, 2009).

\subsection{Sterilization parameters for the jacketed bioreactor}

The sterilization process lethality is a function of steam temperature and time. Due to this, there are different conditions that can achieve an aseptic acceptable level. In order to compare several sterilization, treatments it is necessary to consider the cumulative lethality value (Alonso et al., 2013). 
To define the combination of parameters for tests, the central point was chosen from the definition of lethality given by standard ISO17665-1:2006(E) (Istchenko \& No, 2006) (sterilization temperature $121^{\circ} \mathrm{C}$ for $15 \mathrm{~min}$ ) and the related equidistant points.

Figure 2 shows lethal-rate and temperature-time profiles for examined conditions (Young \& Lasher, 1995). It is shown that treatments with low value parameters $\left(119{ }^{\circ} \mathrm{C}, 10 \mathrm{~min}\right)$ reach a maximum temperature nearly $85^{\circ} \mathrm{C}$, which differs $36^{\circ} \mathrm{C}$ from the standard sterilization temperature (Simpson, Nuñez, \& Almonacid, 2015).

The difference of temperatures diminishes as the medium is treated with longer sterilization periods at constant temperature. With the treatments of 15 and 20 minutes of sterilization, the differences were 30 and $28^{\circ} \mathrm{C}$, respectively. This behavior is also noted in the other heat treatments. It was expected that the most severe treatment $\left(123^{\circ} \mathrm{C}, 20 \mathrm{~min}\right.$ ) had a closer temperature to $121^{\circ} \mathrm{C}$, showing a maximum temperature of $94{ }^{\circ} \mathrm{C}$. This supports the findings of Morales-Blancas et al. (2005), were the progressive increase of temperature follows a known behavior of heat dynamics at the cold point of a vessel (Breu, Guggenbichler, \& Wollmann, 2007; Morales-Blancas, E. Pérez, D. Rodríguez, C. Simpson, 2005).

Figure 2 shows how autoclaving temperature grows quickly during heating within a 9-minute come-up time. Similar results in the early heating stage were shown by Singh et al. (2015), observed in both stirred and non-stirred vessels (Singh et al., 2015).

When cooling process starts, it is important to notice that this stage is the longest of the stages, approximately $60 \%$ of the entire sterilization process, if it considers a time between the highest temperature inside the vessel and the final temperature at the end of a sterilization cycle. In order to estimate the parameters of interest, data between operation temperature through maximum temperature inside the bioreactor were taken.

One of the most remarkable observations is that during all experimental runs the highest temperature inside the glass-vessel is obtained after the end of autoclave's sterilization time (Simpson, Almonacid, \& Teixeira, 2003). In addition to this, in all experimental runs within this temperature were less than $121^{\circ} \mathrm{C}$. This means that colony forming units equal zero did not keep a certain temperature value rather than maintain a heating process during the necessary time to fulfill a minimum lethal rate. This value is different for each equipment, as well as the sterilization process, material conductive coefficient, culture medium and the relationship between the chamber's temperature and the bioreactor's temperature such as motor force of heat transfer, among other factors (Choi et al., 2013). The latter was shown in canned food processing, were Matser et al. (2004) demonstrated that a combination of heat and pressure pulses results in the inactivation of spores in $500 \mathrm{ml}$ cans for different types of foods.

This experiment suggests two possible explanations for this behavior. First, the jacket of bioreactors declines heat transfer through inside the vessel due to a reduced contact between the vapor and the liquid medium. Second, molasses is a complex feed stock, in contrast, diluted medium has a more adequate heat transmission for relatively short sterilization time, hence medium with suspended solids require a much longer sterilization time at $121^{\circ} \mathrm{C}$ to ensure sterility (Rogers, 2012). 


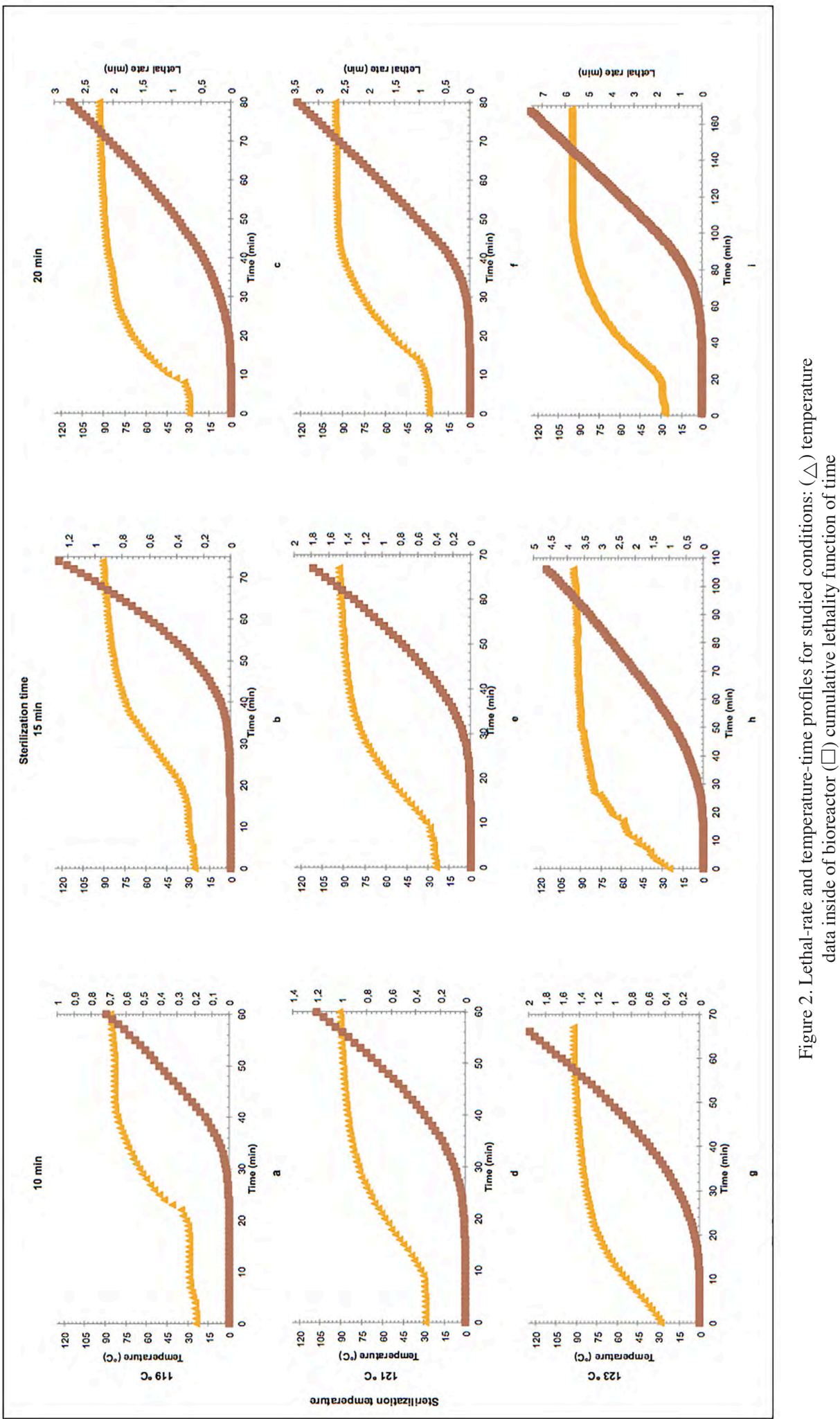




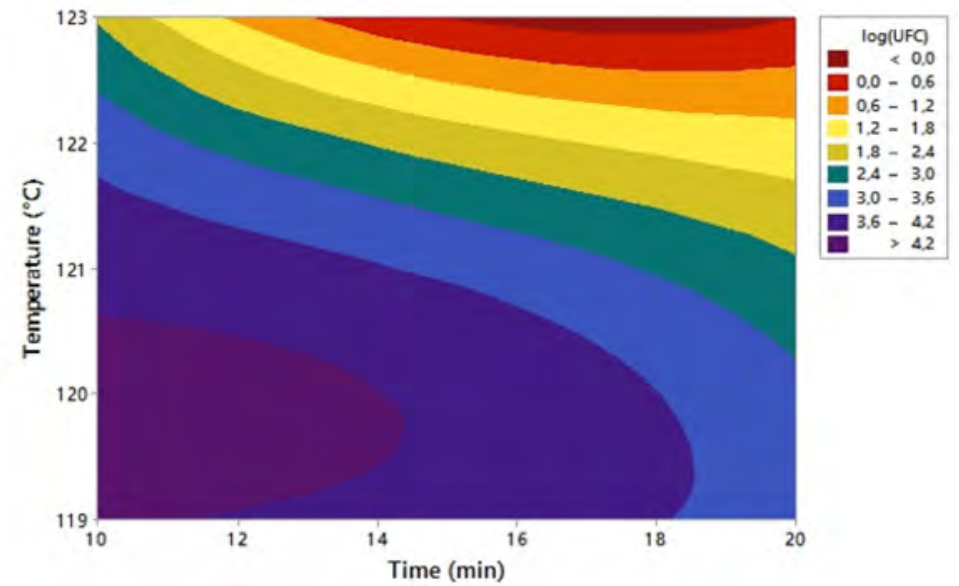

Figure 3. Contour plot of $\log (\mathrm{CFU})$ in function of temperature and time in sterilization processes for a jacketed biorreactor

We used the Ratkowsky nonlinear model as the mathematical model for temperature and time. This model offers advantages in this case if one of the parameters is close to being linear, for which it is possible to reparametrize the offending parameter without disturbing the properties of other parameters. This model is widely used in works of descriptive microbiology (Bernaerts, Versyck, \& Van Impe, 2000; Ratkowsky, 1993; Wang \& Wan, 2008; Zwietering et al., 1991). The implementation of B. cereus strains for sterilization testing (Hariram, U. and Labbe, 2015; Luu-Thi, Grauwet, Vervoort, Hendrickx, \& Michiels, 2014) is suitable in this case, as its spores are known for a high thermic resistance with a $\mathrm{D}$ value of $27 \mathrm{~min}$ at $100{ }^{\circ} \mathrm{C}$ (Ates et al., 2016).

The relationship between temperature, time for sterilization and the CFU at the end of the sterilization process is presented in a contour plot (figure 3). The darker regions represent higher biological content in comparison to the lighter regions.

In the region between 16 and 20 min with near $123^{\circ} \mathrm{C}$ it was clear that the presence of contaminant microorganisms was highly diminished. In contrast, common sterilization conditions of $121^{\circ} \mathrm{C}$ and 15 min still showed the presence of microorganisms in the range of $3 \times 10^{3} \mathrm{UFC}$ and a $F_{0}$ of $1.8 \mathrm{~min}$.

Taking into consideration the results obtained, it is possible to predict the CFU based on $F_{0}$ data. This could offer an interesting basis for future sterilization practices and a methodology as a starting point for sterilization trials in industry and save time and costs. The tridimensional surface chart (figure 4) demonstrates the nonlinear dynamics between time and temperature. In this chart, it is possible to observe the overall behavior of the response variable $(\mathrm{CFU})$ based on temperature and time. There exists a maximum point when temperature and time are $119^{\circ} \mathrm{C}$ and 10 minutes, with a respective minimum point reaching $123{ }^{\circ} \mathrm{C}$ and 20 minutes. For the present investigation, the objective was to reduce the response variable to ensure sterility condition and this is achieved with a minimum value of accumulated lethality of $3 \min$ or $123^{\circ} \mathrm{C}$ and 20 minutes. 


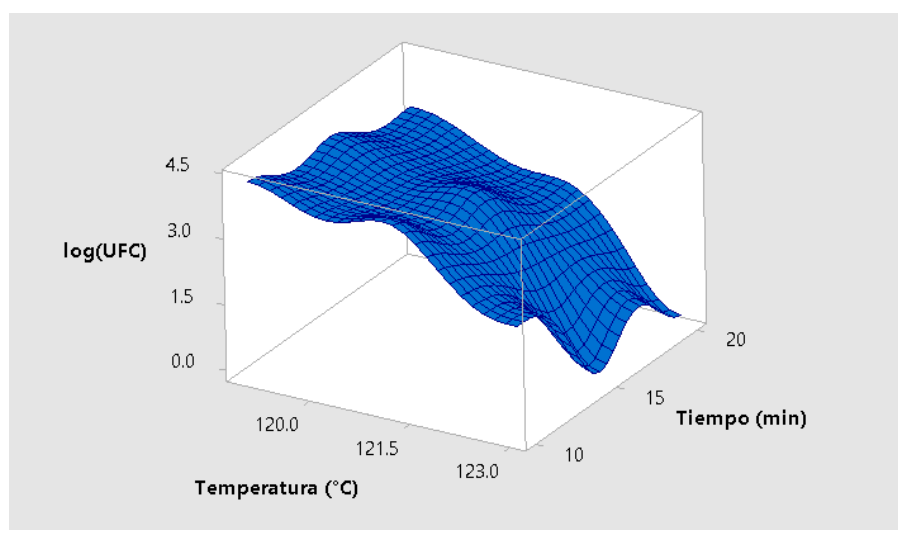

Figure 4. Surface plot of $\log (\mathrm{CFU})$ in function of temperature and time in sterilization processes for a jacketed bioreactor

In figure 5 the graphic behavior of experimental data and Ratkowsky model appears. The nonlinear model was selected with the parameterization option mentioned by Rathowsky (1993), considering a two variable model ( $a$ y $b$ ), to describe a convex curve which represents graphically the thermal deactivation due to the action of temperature.

The CurveExpert ${ }^{\circledR}$ program determined that the correlation coefficient between the model and experimental data is 0,97 . For this article's purpose, this value is regarded as a valid correlation (Ratkowsky, 2002). With this, an analysis coefficient equation was obtained with the following equation:

$$
y=\exp (11,04-1,49 X)
$$

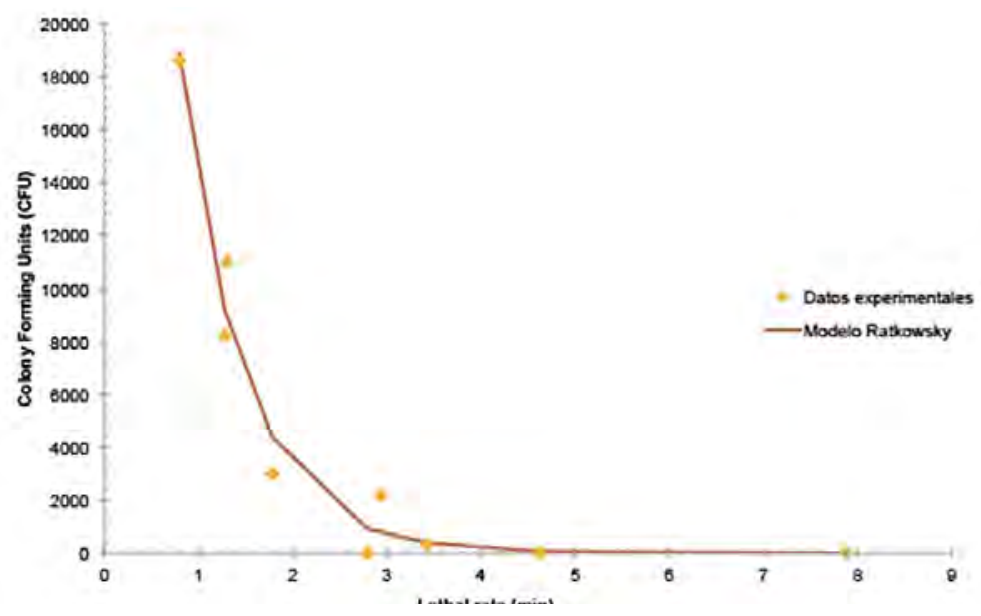

Figure 5. Graphic behavior of experimental data and Ratkowsky correlation curve

The use of this model allows the prediction of results from sterilization trials in jacketed bioreactors, for which it is possible to predict CFU values from initial the 
accumulated lethality of sterilization tests. These results improve quality insurance for the biotechnological industry by the use of sterilization parameters that allow an efficient sterilization with low energy consumption.

\section{CONCLUSIONS}

The Ratkowsky model expressed the relationship between sterilization parameters on lethality and death rate of Bacillus cereus, which exhibited a nonlinear behavior. The Ratkowsky model with parameterization showed a positive correlation of 0,97 between the $F_{0}$ and lethality.

In our study, it was found that a minimum accumulated lethality value of 3,0 min is required for a bioreactor's sterilization assurance, which is equal to at least for 3,0 min at $121{ }^{\circ} \mathrm{C}$. This means to work with a higher temperature due to the progressive increase of lethality in jacked stirred bioreactors. This value is similar to the minimum standard for accumulated lethality established in food standards as mentioned by Choi et al (2013). Consequently, food processed in higher volumes is treated with higher values of lethality to assure overall food safety and quality (Choi et al., 2013).

When analyzing temperature profiles and lethality, a progressive increase over time is noted. In all the cases examined, the maximum temperature inside the container is recorded after finishing the sterilization process. Compared to the experimental runs, the maximum temperature obtained inside the bioreactor was $94^{\circ} \mathrm{C}$, which is $27^{\circ} \mathrm{C}$ Celsius degrees lower than $121^{\circ} \mathrm{C}$.

Based on the contour graphic, the region within 16 and 20 min approximating $123{ }^{\circ} \mathrm{C}$ did not show a relevant presence of microorganisms. In contrast, under these conditions -including common sterilization conditions $\left(121^{\circ} \mathrm{C}\right.$ and $\left.15 \mathrm{~min}\right)-$, it presented microorganisms at an increasing level.

The use of the $F_{0}$ to predict the CFU in sterilization process could be implemented as an important tool for establishing sterilization processes in the industry and reduce the associated costs and trial time of these.

\section{Acknowledgements}

Authors thank Sergio Madrigal-Carballo for his collaboration during the manuscript revision. Authors are grateful for the financial support provided by CeNAT-CONARE grant and CENIBiot. The authors declare that they have no competing interests.

\section{NOMENCLATURE}

D: decimal reduction ( $\mathrm{min}$ )

$\mathrm{D}_{\mathrm{T} 1}$ : decimal reduction at initial temperature (min)

$\mathrm{D}_{\mathrm{T} 2}: \quad$ decimal reduction at final temperature (min)

$\mathrm{k}_{\mathrm{d}}$ : thermal death constant $\left(\mathrm{s}^{-1}\right)$

$\mathrm{N}$ : number of viable organisms 
$\mathrm{N}_{0}: \quad$ initial number of viable organisms

t: $\quad$ tiempo (min)

$\mathrm{z}: \quad$ temperature sensitivity $\left({ }^{\circ} \mathrm{C}\right)$

\section{REFERENCES}

Alonso, A. A., Arias-Méndez, A., Balsa-Canto, E., García, M. R., Molina, J. I., Vilas, C., \& Villafín, M. (2013). Real time optimization for quality control of batch thermal sterilization of prepackaged foods. Food Control, 32(2), 392-403. https://doi.org/10.1016/j. foodcont.2013.01.002

Armenante, P. M., \& Leskowicz, M. A. (1990). Design of Continuous Sterilization Systems for Fermentation Media Containing Suspended Solids. Biotechnology Progress, 6(4), 292-306. https://doi.org/10.1021/bp00004a011

Ates, M. B., Skipnes, D., Rode, T. M., \& Lekang, O. I. (2016). Comparison of spore inactivation with novel agitating retort, static retort and combined high pressure-temperature treatments. Food Control, 60, 484-492. https://doi.org/10.1016/j.foodcont.2015.08.033

Bernaerts, K., Versyck, K. J., \& Van Impe, J. F. (2000). On the design of optimal dynamic experiments for parameter estimation of a Ratkowsky-type growth kinetics at suboptimal temperatures. International Journal of Food Microbiology, 54(1-2), 27-38. https://doi. org/10.1016/S0168-1605(99)00140-3

Boca, B. M., Pretorius, E., Gochin, R., Chapoullie, R., \& Apostolides, Z. (2002). An Overview of the Validation Approach for Moist Heat Sterilization , Part I. Pharmaceutical Technology, (September), 62-67.

Boeck, L. D., Alford, J. S., Pieper, R. L., \& Huber, F. M. (1989). Interaction of media components during bioreactor sterilization: definition and importance of R0. Journal of Industrial Microbiology, 4(3), 247-252. https://doi.org/10.1007/BF01574082

Boeck, L. D., Wetzel, R. W., Burt, S. C., Huber, F. M., Fowler, G. L., \& Alford, J. S. (1988). Sterilization of bioreactor media on the basis of computer calculated thermal input designated as F0. Journal of Industrial Microbiology, 3(5), 305-310. https://doi.org/10.1007/BF01569531

Breu, F., Guggenbichler, S., \& Wollmann, J. (2007). Thermal Processing of Packaged Foods. Vasa. https://doi.org/10.1007/978-0-387-72250-4

Burghaus, I., \& Dette, H. (2014). Optimal designs for nonlinear regression models with respect to non-informative priors. Journal of Statistical Planning and Inference, 154(1), 12-25. https://doi.org/10.1016/j.jspi.2014.05.009 
Choi, S., Cheigh, C., \& Chung, M. (2013). Optimization of processing conditions for the sterilization of retorted short-rib patties using the response surface methodology. MESC, 94(1), 95-104. https://doi.org/10.1016/j.meatsci.2012.12.016

Fernlund, G., Mobuchon, C., \& Zobeiry, N. (2018). 2.3 Autoclave Processing. In Comprehensive Composite Materials II (pp. 42-62). Elsevier. https://doi.org/10.1016/ B978-0-12-803581-8.09899-4

Hariram, U. and Labbe, R. G. (2015). Growth and Inhibition By Spices of Groth From Spores of Enteroxigenic Bacillus Cereus in Cooked Rice. Food Control, 64, 60-64. https://doi. org/10.1016/j.foodcont.2015.12.024

Huang, L., Hwang, C. A., \& Phillips, J. (2011). Evaluating the Effect of Temperature on Microbial Growth Rate-The Ratkowsky and a Bělehrádek-Type Models. Journal of Food Science, 76(8). https://doi.org/10.1111/j.1750-3841.2011.02345.x

Iso/Ts 17665-2:2009. (2009). Sterilization of health care products -- Moist heat -- Part 2: Guidance on the application of ISO 17665-1. International Organization for Standardization.

Istchenko, R., \& No, O. (2006). International Standard, 2005, 22674. https://doi.org/10.5594/ J09750

Karayannakidis, P. D., Apostolidis, E., \& Lee, C. M. (2014). Comparison of direct steam injection and steam-jacketed heating in squid protein hydrolysis for energy consumption and hydrolysis performance. LWT - Food Science and Technology, 57(1), 134-140. https:// doi.org/10.1016/j.lwt.2014.01.012

Lau, W. L., Reizes, J., Timchenko, V., Kara, S., \& Kornfeld, B. (2015). Heat and mass transfer model to predict the operational performance of a steam sterilisation autoclave including products. International Journal of Heat and Mass Transfer, 90, 800-811. https://doi. org/10.1016/j.jheatmasstransfer.2015.06.089

Luu-Thi, H., Grauwet, T., Vervoort, L., Hendrickx, M., \& Michiels, C. W. (2014). Kinetic study of Bacillus cereus spore inactivation by high pressure high temperature treatment. Innovative Food Science \& Emerging Technologies, 26, 12-17.https://doi.org/10.1016/j.ifset.2014.07.005

Matser, A. M., Krebbers, B., Van Den Berg, R. W., \& Bartels, P. V. (2004). Advantages of high pressure sterilisation on quality of food products. Trends in Food Science and Technology, 15(2), 79-85. https://doi.org/10.1016/j.tifs.2003.08.005

Morales-Blancas, E. Pérez, D. Rodríguez, C. Simpson, R. (2005). Simulation of thermal processing of non-symmetric and irregular-shaped foods vacuum packed in retortable pouches. Presentation at IFT Meeting, New Orleans. 
Munarin, F., Bozzini, S., Visai, L., Tanzi, M. C., \& Petrini, P. (2013). Sterilization treatments on polysaccharides: Effects and side effects on pectin. Food Hydrocolloids, 31(1), 74-84. https://doi.org/10.1016/j.foodhyd.2012.09.017

Noble, P. T. (1992). Modeling transport processes in sterilization-in-place. Biotechnology Progress, (8), 275-284. https://doi.org/10.1021/bp990013k

Padrón, J. A., Fernández, J., Suárez, J., Pucheta, L. L., Limia, G., Carballosa, L., .. Carcache, J. (2001). Determinación del tiempo equivalente acumulado durante los ciclos de esterilización, por vapor saturado, en un fermentador empleado en la producción de vacunas, (2), 1-6.

Ratkowsky, D. (1993). Principles of nonlinear regression modeling. Journal of Industrial Microbiology, 12, 195-199. https://doi.org/10.1007/BF01584190

Ratkowsky, D. (2002). Some examples of and some problems with, the use of nonlinear logistic regression in predictive food microbiology. International Journal of Food Microbiology, 73(2-3), 119-125. https://doi.org/10.1016/S0168-1605(01)00643-2

Rogers, W. J. (2012). Steam and dry heat sterilization of biomaterials and medical devices. In Sterilisation of Biomaterials and Medical Devices (pp. 20-55). Elsevier. https://doi. org/10.1533/9780857096265.20

Schneider, P. M. (2014). Evaluation of a new rapid readout biological indicator for use in 132 ${ }^{\circ} \mathrm{C}$ and $135^{\circ} \mathrm{C}$ vacuum-assisted steam sterilization cycles. American Journal of Infection Control, 42(2), e17-e21. https://doi.org/10.1016/j.ajic.2013.09.015

Sherer, E., Hannemann, R. E., Rundell, A. E., \& Ramkrishna, D. (2009). Application of stochastic equations of population balances to sterilization processes. Chemical Engineering Science, 64(4), 764-774. https://doi.org/10.1016/j.ces.2008.05.011

Simpson, R., Almonacid, S., \& Teixeira, A. (2003). Bigelow's General Method Revisited: Development of a New Calculation Technique. Journal of Food Science, 68(4), 1324-1333. https://doi.org/10.1111/j.1365-2621.2003.tb09646.x

Simpson, R., Nuñez, H., \& Almonacid, S. (2015). Modeling thermal processing and reactions. In S. Bakalis, K. Knoerzer, \& P. J. Fryer (Eds.), Modeling Food Processing Operations (pp. 67-93). https://doi.org/10.1016/B978-1-78242-284-6.00003-9

Singh, A. P., Singh, A., \& Ramaswamy, H. S. (2015). Modification of a static steam retort for evaluating heat transfer under reciprocation agitation thermal processing. Journal of Food Engineering , 153, 63-72. https://doi.org/10.1016/j.jfoodeng.2014.12.001

Singh, V., Hensler, W., \& Fuchs, R. (1989). Optimization of batch fermentor sterilization. Biotechnology and Bioengineering, 33(5), 584-591. https://doi.org/10.1002/bit.260330511 
Wang, J., \& Wan, W. (2008). Effect of temperature on fermentative hydrogen production by mixed cultures. International Journal of Hydrogen Energy, 33(20), 5392-5397. https://doi. org/10.1016/j.ijhydene.2008.07.010

Wood, J. P., Lemieux, P., Betancourt, D., Kariher, P., \& Griffin, N. (2008). Pilot-scale experimental and theoretical investigations into the thermal destruction of a Bacillus anthracis surrogate embedded in building decontamination residue bundles. Environmental Science and Technology, 42(15), 5712-5717. https://doi.org/10.1021/es7021945

Young, J. H., \& Lasher, W. C. (1995). Dimensionless Parameters as Design Guidelines for Sterilization Dead-Ended Tubes, 2-7.

Zwietering, M. H., de Koos, J. T., Hasenack, B. E., de Witt, J. C., \& van’t Riet, K. (1991). Modeling of bacterial growth as a function of temperature. Applied and Environmental Microbiology, 57(4), 1094-1101. https://doi.org/2059034 